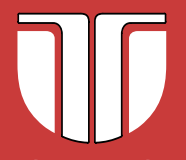

TECHNICAL UNIVERSITY

OFCLUJ-NAPOCA
JOURNAL OF ANCIENT HISTORY AND ARCHAEOLOGY

Institute of Archeology and Art History of

Romanian Academy Cluj-Napoca

Technical University Of Cluj-Napoca

\title{
Journal of Ancient History and Archaeology
}

DOI: http://dx.doi.org/10.14795/j.v8i1

ISSN 2360 - 266X

ISSN-L2360 - 266X

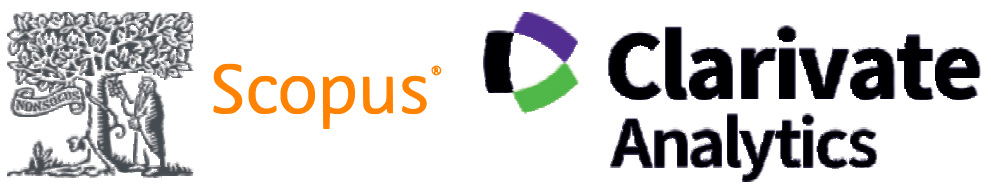

Central and Eastern Eurodean Online Library 


\section{CONTENTS}

\section{STUDIES}

\section{ANCIENT HISTORY}

\section{Alin HENT, Daniel CIOATĂ}

DEBUNKING A MYTH: THE DACIAN CURVED SWORD BETWEEN HISTORIOGRAPHICAL DISCOURSE AND THE ARHEOLOGICAL REALITIES

\section{NUMISMATICS}

\section{Emre ERDAN}

IT'S A SWORD, IT'S A SCABBARD, IT'S TISNA COINS WITH DEPICTION OF PERSIAN AKINAKES

\section{Metodi MANOV}

AN UNKNOWN COIN DIE OF AUGUSTUS (27 BC - 14 AD), FOUND NEAR OESCUS ON THE DANUBE

\section{Cristian GĂZDAC, Marius-Mihai CIUTĂ}

RECOVERING CULTURAL HERITAGE. FORENSIC ARCHAEOLOGY AND NUMISMATICS - THE ROMAN HOARD FROM THE PRISACA HILL (ROMANIA)

\section{François de CALLATAŸ}

A STILL LIFE OIL PAINTED BY HENDRIK VANDER BORGHT IN 1650 WITH ANCIENT COINS FROM DACIA: A HIGHLY EDUCATED WORK AND A POLITICAL MANIFESTO

\section{REVIEWS}

\section{Csaba SZABÓ}

SCHEIDEL, WALTER (ED.), THE SCIENCE OF ROMAN HISTORY. BIOLOGY, CLIMATE AND THE FUTURE OF THE PAST, PRINCETON/OXFORD, PRINCETON UNIVERSITY PRESS, 2018.

\section{Annamária-Izabella PÁZSINT}

RADA VARGA, CARVING A PROFESSIONAL IDENTITY. THE OCCUPATIONAL EPIGRAPHY OF THE LATIN WEST, ARCHAEOPRESS ROMAN ARCHAEOLOGY 73, OXFORD, ARCHAEOPRESS, 2021

\section{Matthew G. MARSH}

TOURAJ DARYAEE \& KHODADAD REZAKHANI. FROM OXUS TO EUPHRATES: THE WORLD OF LATE ANTIQUE IRAN. ANCIENT IRAN SERIES VOL. 1 IRVINE/LOS ANGELES, CA: JORDAN CENTRE FOR PERSIAN STUDIES/ FARHANG FOUNDATION, 2017

$$
\begin{aligned}
& \text { Design \& layout: } \\
& \text { Petru Ureche }
\end{aligned}
$$




\section{Studies}

NUMISMATICS

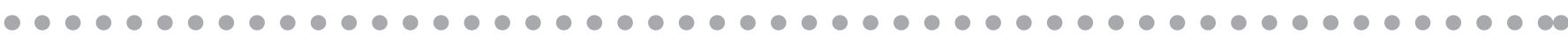

RECOVERING CULTURAL

HERITAGE.

FORENSIC ARCHAEOLOGY AND

NUMISMATICS - THE ROMAN

HOARD FROM THE PRISACA

HILL (ROMANIA)

\begin{abstract}
Combining forensic archaeology and numismatic methods of investigations, the present study identify a new Roman hoard buried in the context of the Dacian wars.

Furthermore, the composition and the findspot of this hoard reveal the Roman functionality of the site where the hoard was discovered.

Keywords: Roman hoard, metal detecting, Roman garrison, Prisaca Hill.
\end{abstract}

D etween 1995 and 2005, Romania was a real paradise for metal detecting, especially eluding legal aspects. A large number of archaeological sites, as well as numerous artefacts - all parts of the national cultural heritage of Romania - fell to the abominable enterprises of all elements involved in trafficking antiquities: metal detectorists, intermediaries, dealers, auction houses. However, since 2005, the authorities were getting more and more successfully in preventing, protecting and recovery, either entirely or partially, this looted national cultural heritage. During this process, also a large number of suspects in charge with a systematic looting of archaeological sites through metal detecting were identified. ${ }^{1}$

Among the first positive results following the involvement of authorities to protect the cultural heritage were the increase of the artefacts' number that entered local and national museums' collections. Then, the last years witnessed the scholarly publication of many of these recovered objects, which increased the knowledge and the value of the Romanian cultural heritage. ${ }^{2}$

The present study tries to offer such a case-study where the forensic action combined with the historical, archaeological and the numismatic approaches may throw a new light on old historical debates and offer new data on specific major historical events such as the Dacian wars of AD 101-102 and 105-106.

${ }^{1}$ LAZĂR 2006; LAZĂR 2008; LAZĂR 2009; LAZĂR 2013; BĂRBULESCU 2016; CIUTĂ 2016a; CIUTĂ 2016b; CIUTĂ 2019; TEODOR 2014; TEODOR 2018; BUNOIU 2016; PAVEL 2017.

2 PETAC/POPA 2018; CONSTANTINESCU et alii 2018; GĂZDAC 2020; CIUTĂ/PURECE 2018.

\section{Cristian GĂZDAC}

Institute of Archaeology Cluj-Napoca Babeș-Bolyai University, Cluj-Napoca cgazdac2000@yahoo.co.uk

Marius-Mihai CIUTĂ "Lucian Blaga" University Sibiu mariusciuta@yaho.com

DOI: $10.14795 /$ j.v8i1.589

ISSN $2360-266 \mathrm{X}$

ISSN-L 2360 - 266X 


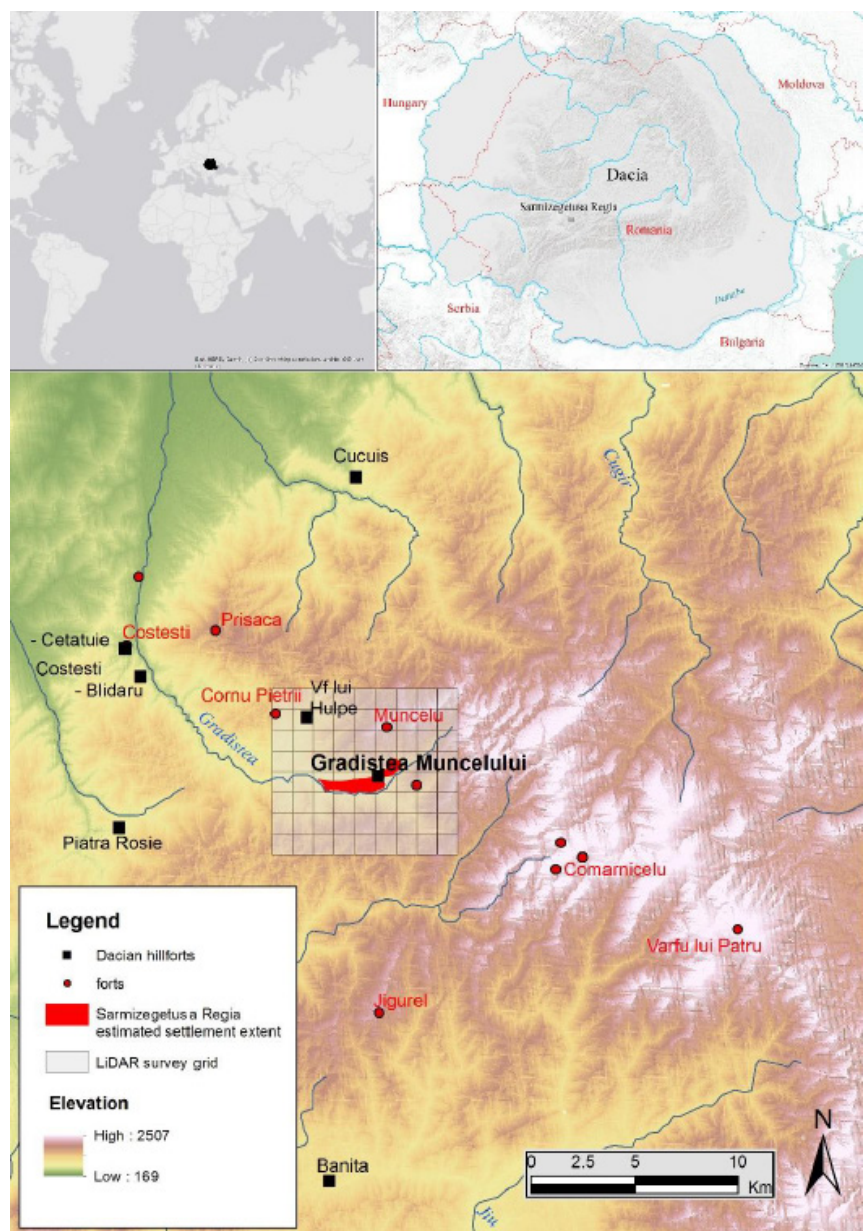

Fig. 1. Gradual maps for pointing out the location of Prisaca Roman fort (after OLTEAN/FONTE 2021, 3, fig. 1). systematic investigations, only some testing excavations in the 1940's mentioned by C. Daicoviciu and Al. Ferenczi. ${ }^{4}$ A field survey took place in in the 1950 's. ${ }^{5}$ Located at an altitude of 1,219 , this fortification has a good strategic position controlling the Grădiște Valley on the segment CosteștiOrăștie, as well as the high paths running southward from the River Mures Valley. At the same time, this fortification is located opposite to the Dacian citadels Costești-Cetățuie (1,200 m straight line) and controls it due to a higher position (Fig. 2), as well as it does for the Dacian settlements from the Vârtoapele Hill.

The size of this fortification was given by C. Daicoviciu as $300 \times 100-120 \mathrm{~m}$ with an irregular shape following the terrain configuration. It is NNE-SSW orientated with round corners. The peripheral wall was built in stones only with a fir wooden palisade. ${ }^{6}$ Outside fortification, red and grey wheel-made pottery, as well as hand-made porous one was found. In the vallum were found: stones, large bits of coal, and traces of burnt fir beams.

In the academic literature, the fortification was considered as a former Roman fort but the discovery of some La Tène pottery within and near the fortification was considered an argument for a possible Dacian functionality of the site. ${ }^{8}$ Other scholars have also forwarded a medieval dating of the site. ${ }^{9} \mathrm{H}$. Daicoviciu forwarded the theory of a temporary Roman camp, ${ }^{10}$ a hypothesis accepted by recent studies mentioning the fortification on the Prisaca Hill. ${ }^{11}$

The discussion with one of the finders also revealed that the hoard was found on the inner side of the fortification's northern limit.

\section{THE FORENSIC}

In February 2006, in a captatio benevolentiae approach, one of the suspects has offered to the authorities a batch of 92 ancient coins coming from the area of Grădiștie Valley. That area is a wellknown archaeological reservation, a hinterland of the former Dacian kingdom capital - Sarmizegetusa Regia - extremely rich in Dacian and Roman artefacts, and, therefore under the metal detectorists raids between 2000 and 2005. (Fig. 1).

Initially, the investigators placed the findspot for this lot within the locality of Ludeștii de Sus (Strugari) (commune of Orăștioara de Sus, Hunedoara County). However, recently, following a new discussion with the metal detectorist, he clearly pointed towards a spot located on a top of the Luncani plateau, known as the Prisaca Hill (among the locals, also known as the Drăgăneasa Hill) (Fig. 1).

\section{THE FORENSIC ARCHAEOLOGY}

The precise pointing to the spot where the coins were found produced a first positive result.

The plateau on the Prisaca Hill was already known for hosting an old fortification. ${ }^{3}$ The site never underwent

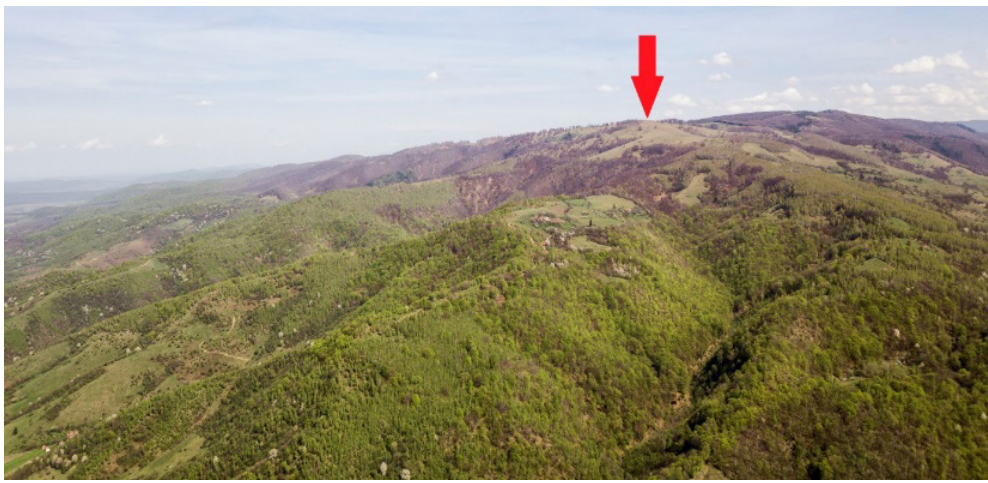

Fig. 2. Drone photo, alt. $967 \mathrm{~m}$, above the Costești-Cetăție hillfort looking towards the Prisaca Hill. To the left the River Mureș Valley (credits: C. Șuteu).
206, 253; LUCA 2005, 73; LUCA 2005b, 52 ; GHEORGHIU 2005. In Lista Monumentelor Istorice (2015), the site is registred under the name Castrul roman de la Costești the Roman fort from Costești], cod: HD-Is-A-03180, village Costeşti-Deal; commune Orăştioara de Sus, "Prisaca". In the National Archaeological Records [Repertoriului Arheologic Național] (code 90379.04), in: military presence, rectangular fort with round corner following the terrain configuration; stone and earth vallum (http://ran. cimec.ro/sel.asp?codlmi=HD-I-s-A-03180) (accessed on 23.01.2021).

${ }^{4}$ DAICOVICIU/FERENCZI 1951, 46.

${ }^{5}$ DAICOVICIU et alii 1959, 381.

6 DAICOVICIU/FERENCZI 1951, 46.

DAICOVICIU et alii 1959, 381.

8 DAICOVICIU/FERENCZI 1951, 46

9 STEFAN 2005, 284-285 (apud MARCU/SZABÓ 2020, 77).

10 DAICOVICIU/FERENCZI/GLODARIU 1989, 206.

11 MARCU/SZABÓ 2020, 76, fig. 15; 77; 


\section{The Forensic Numismatics}

The analysis of the batch of the 92 coins has revealed that the metal detectorist under investigations has, in fact, found more than one hoard. of Thassos.

One hoard was consisting of at least six tetradrachms

The other coins were all denarii, republican and imperial issues.

Based on the patterns of Roman hoards' structure in pre- and Roman Dacia and a specific state of conservation of some of these denarii, ${ }^{12}$ it was obvious that we deal with two different hoards. One, it consists of Republican and imperial denarii up to the $4^{\text {th }}$ consulate of Trajan (AD 101-102). The other Roman hoard consisted of issues from Flavians to the reign of Antoninus Pius. ${ }^{13}$

This aspect has led us to the conclusion that these hoards come from three different places.

Therefore, another round of discussions with the metal detectorist could have brought more essential information on these monetary discoveries.

In this study, we are presenting the case of the hoard that was actually found within the fortification on the Prisaca Hill. ${ }^{14}$

Following the information provided by one of the finders the hoard was discovered in August or September 2005, in a pit on the northern limit of the garrison, on the inner side.

Originally, the hoard comprised 183 denarii found in a ceramic vessel. The coins were split among the metal detectorists. As some of the coin $s$ have been already dispersed by the finders, at the time of presenting the batch of 92 coins, only 44 denarii from this hoard were available for the study (see catalogue).

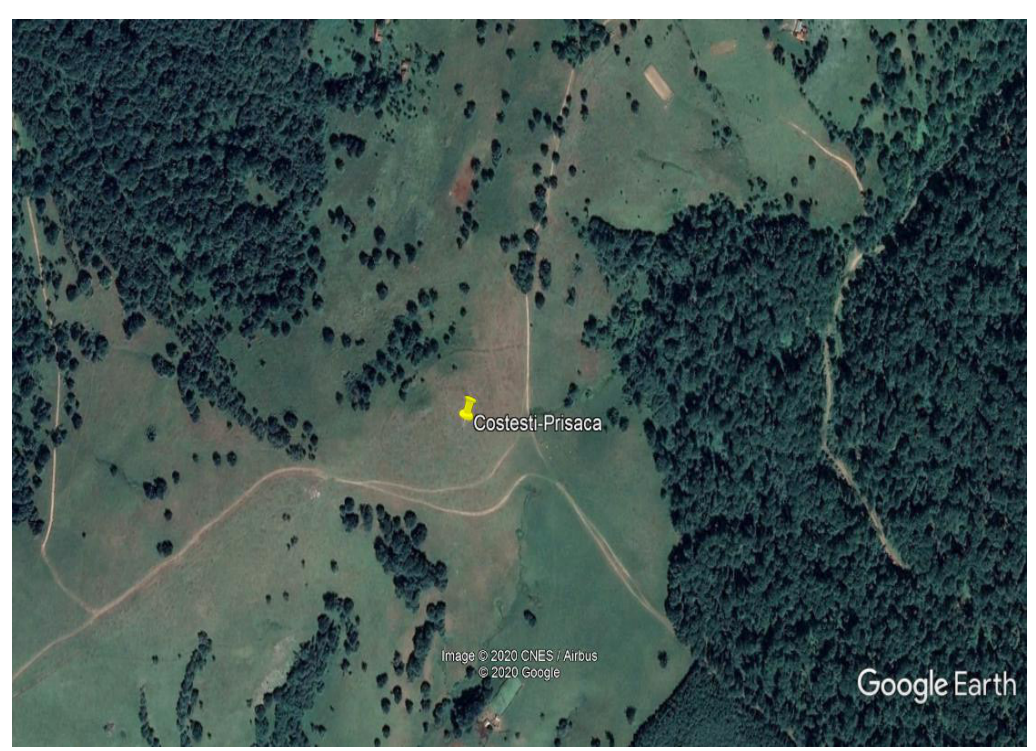

Fig. 3. The Prisaca garrison location, nowadays (Google Earth).

\footnotetext{
12 Despite the efforts of the finder(s) to clean the coins of the second Roman hoard, the artefacts still preserve traces of green oxides.

${ }^{13}$ A similar conclusion was reached during the expertise requested by the Appeal Court of Alba Iulia. The expertise was carried out by E. Oberländer-

Târnoveanu (National History Museum of Romania, Bucharest).

${ }^{14}$ The other two hoards will be the topic of two following studies.
}

On the basis of issuers these coins are as follows:

\begin{tabular}{|c|c|c|c|}
\hline \multirow{2}{*}{ Issuer } & \multicolumn{2}{|c|}{ No. denarii } & \multirow{2}{*}{ Total } \\
\hline & Rome & Travelling mint & \\
\hline Roman Republic & 11 & 2 & 13 \\
\hline VESPASIAN & 14 & & 14 \\
\hline Vespasian (Augustus) & 11 & & 11 \\
\hline Titus (Caesar) & 1 & & 1 \\
\hline Domitian (Caesar) & 2 & & 2 \\
\hline DOMITIAN & 14 & & 14 \\
\hline TRAJAN & 3 & & 3 \\
\hline Total & 42 & 2 & 44 \\
\hline
\end{tabular}

At the first sight, this quite well-proportioned structure of what is left from what was once a hoard of 183 republican and imperial denarii may look atypically for a hoard ending with early issue of Trajan. One will expect a fully recovered hoard - of over 100 pieces - ending with early coins of Trajan to may have a small amount of republican denarii - dominated by Mark Antony's 'legionary' series -; the absence of Augustus - Claudius I coins, following the monetary reforms of Nero, Domitian; ${ }^{15}$ increase of number Vespasian's coins (AD 69-79); some pieces for the short reign of Titus (AD 79-81); the increase of coin number for the reign of Domitian (AD 81-96); again, maybe, some coins for another short reign - Nerva (AD 96-98), and ending with few coins of Trajan early issues up to the $4^{\text {th }}$ consulate (AD 101-102). ${ }^{16}$

In fact, the way the 44 coins are distributed by issuers indicate a common practice among the metal-detectorists with less knowledge - or not at all - on Ancient History to split the 'prey' among themselves: proportionally, same amount of poor state of preservation coins, middle state of preservation ones and the 'beautiful' ones, mainly based on the portrait. Certainly, in this case, the Trajan's coins were the fewer ones.

The odyssey of this hoard - circumstances of discovery, the absence of any information on the missing coins, the way it was split - does not allow further numismatic comments based on statistics. However, it is certain, that we are dealing with another hoard buried and not recovered during the Dacian wars. Similar hoards have been already well-documented in the area surrounding the Dacian kingdom center from Sarmizegetusa Regia (fig. 4). The most recent discovery is the small deposit of six denarii ending with a Trajan's coins of AD 101-102 found in a Roman edifice within the precinct of Sarmizegetusa Regia. ${ }^{17}$
${ }_{15}$ BUTCHER/PONTING 2014, 201-238; 377-408.

${ }^{16}$ For the evidence on the structures for silver hoards' ending with early issues of Trajan (AD 98-102), see the application Coin Hoards of the Roman Empire at: https://chre.ashmus.ox.ac.uk/ (accessed on 23.01.2021). 17 MATEESCU-SUCIU/GHEORGHIU/GĂZDAC 2016, 108; 128; fig. 23.; https://chre.ashmus.ox.ac.uk/hoard/17492. 


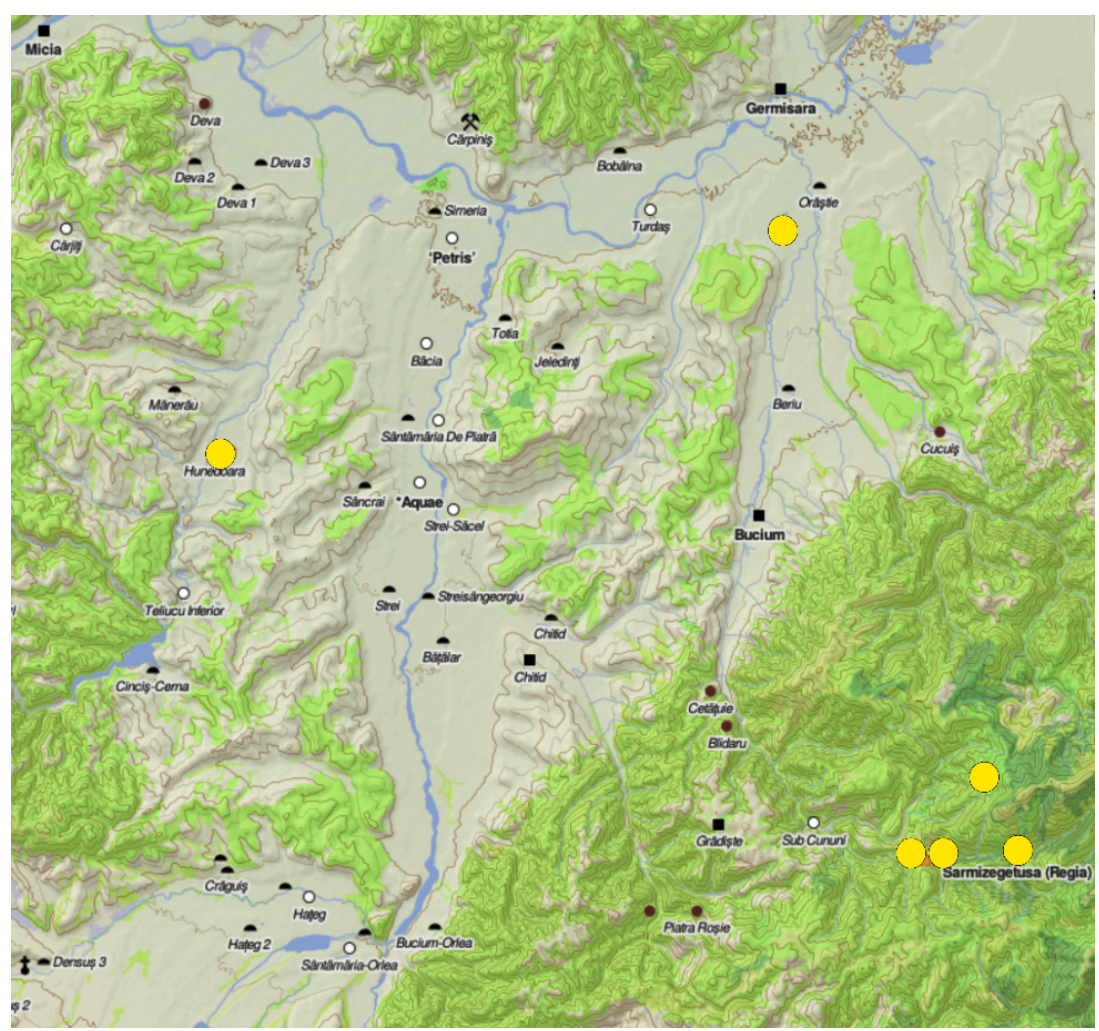

Fig. 4. Map of hoards ending with early coins of Trajan (AD 98-102) (based on Coin Hoards of the Roman Empire, https://chre.ashmus.ox.ac.uk/).

\section{Conclusions}

Forensic investigations in the field of securing cultural heritage, beside recovering, at least, partially, a Roman hoard has also led to the solving a historical aspect. The discovery of a Roman hoard ending with imperial denarii demonstrate that the fortification on the Prisaca Hill was a military garrison. The hiding of this hoard could occur between AD 102 to 106 , as the latest coin can serve only as a terminus post quem index, as well as the hoard is not entirely preserved.

At the same time, the burial of the hoard in association with the discovery of traces of coal and a burnt fir beams indicate the occurrence of a violent event that led not only to the hiding of the hoard but also to its non-recovery.

\section{ACKNOWLEDGEMENTS}

We express here our gratitude to Nicolae Popa and Florin Marc directly involved in gather the information regarding many aspects of the forensic investigations. Thanks go to Dr. Răzvan Mateescu (National History Museum of Transylvania Cluj-Napoca, Romania) for providing us with references and information on various aspects regarding the site on the Prisaca Hill.

\section{REFERENCES}

\section{BĂRBULESCU 2016}

Bărbulescu, M., Arheologia, azi, în România (Cluj-Napoca: Ideea Design \& Print).

\section{BUNOIU 2016}

Bunoiu, V., Detectoarele de metale în România vulnerabilitate națională în protejarea patrimoniului arheologic. In: Musteață, S. (ed), Tendințe curente în protejarea patrimoniului arheologic în România și Republica Moldova (Iași-Chișinău: Arc), 149-156.

\section{BUTCHER/PONTING 2014}

Butcher, K./Ponting, M., The metallurgy of Roman silver coinage. From the reform of Nero to the reform of Trajan (Cambridge: University Press).

\section{CIUTĂ 2016a}

Ciută, M-M., Detectoriştii siturilor arheologice: incercare de realizare a profilului detectoristului din România (1990-2016). In: Musteață, S. (ed), Tendințe curente în protejarea patrimoniului arheologic în România și Republica Moldova (IașiChișinău: Arc), 135-149.

CIUTĂ 2016b

Ciută, M-M., Detectorismul, între amatorism şi nevoia de îmbogăţire. O încercare de schiţă a profilului detectoristului din România (19932016), Anuarul Institutului de Cercetări SocioUmane Sibiu 23, 99-108.

CIUTĂ 2019

Ciută, M-M., Patrimoniul cultural din România. Legislație, starea actuală, Tendințe, Post-doctoral thesis, University Lucian Blaga of Sibiu, Mss.

\section{CIUTĂ/PURECE 2018,}

Ciută, M-M./Purece, S., Tezaurul monetar roman de la Micești (Mun. Alba Iulia, jud. Alba), Studia Universitatis Cibiniensis. Series Historica 15, 25 - 36.

\section{CONSTANTINESCU et alii 2018}

Constantinescu, B./Ciută, M-M./Popa, N./Cristea-Stan, D./ Oberländer-Târnoveanu, E., Considerații privind tezaurul compus din 12 monede de tip Răduleşti-Hunedoara recuperat în urma unor săpături ilegale din zona Dealul Muncelului, vest de Sarmizegetusa Regia, ArheoVest 6, 667681.

\section{DAICOVICIU/FERENCZI 1951}

Daicoviciu C., Ferenczi Al., Așezările dacice din Munții Orăștiei (București: Academiei R. P. Romîne).

\section{DAICOVICIU 1964}

Daicoviciu H., Addenda la "Așezările dacice din Munții Orăștiei", Acta Musei Napocensis 1, 111-125.

\section{DAICOVICIU et alii 1959}

Daicoviciu, C./Floca, O./Gostar, N./Daicoviciu H., Santierul arheologic Grădiștea de Munte, Materiale și Cercetări Arheologice 5, 379-402. http://www.sarmizegetusa. org/doc/Daicoviciu\%20C.\&\%20colaboratorii\%20-\%20 Santierul\%20arheologic\%20Gradistea\%20de\%20Munte1956-(MCA,V,1958).pdf.

\section{DAICOVICIU/FERENCZI/GLODARIU 1989}

Daicoviciu, H./Ferenczi Șt./Glodariu I., Cetăți și așezări dacice în sud-vestul Transilvaniei (București: Științifică și Enciclopedică).

\section{GHEORGHIU 2005}

Gheorghiu, G., Dacii pe cursul mijlociu al Mureșului: (sfârşitul sec. II a. Ch. - începutul sec. II p. Ch.), (Cluj-Napoca: Mega).

\section{LAZĂR 2006}

Lazăr, A., Despre regimul de protejare al bunurilor aparținând unui sit arheologic. In Lazăr, A., Condruz, A., (eds.) Corpus Juris Patrimonii (București: Lumina Lex). 


\section{LAZĂR 2008}

Lazăr, A., Combaterea criminalităţii contra Patrimoniului Cultural Naţional. In: Lazăr, A. et. alii (eds.), Combaterea criminalității contra patrimoniului arheologici. Fighting the Criminality against the Archaeological Haritage [Patrimonium 1] (București: Lumina Lex), 125-149.

LAZĂR 2013

Lazăr, A., „Recuperarea trecutului”. Despre circumstanţele repatrierii tezaurelor dacice sustrase din situl arheologic Sarmizegetusa Regia. In: Lazăr, A. et alii (eds.), Combaterea traficului cu bunuri culturale - recuperarea trecutului. Fighting the trafficking in cultural goods - recovering the past [Patrimonium 3] (Bucureșt: Universul Juridic), 48-70.

\section{LAZĂR/LAZĂR 2009}

Lazăr, A./Lazăr, A.A., Metodologia investigării infracţiunilor din domeniul patrimoniului cultural national. In: Lazăr et alii (eds.), Combaterea criminalităţii contra patrimoniului cultural naţional [Patrimonium 2] (Cluj-Napoca: Mega), 391-474.

\section{LUCA 2005a}

Luca, S.A., Arheologie și istorie (III) Descoperiri din județul Hunedoara [Bibliotheca Septemcastrensis 11] (București: Economică).

LUCA 2005b

Luca, S.A., Repertoriul arheologic al județului Hunedoara [Bibliotheca Septemcastrensis 14] (Alba Iulia: Altip).

\section{MARCU/SZABÓ 2020}

Marcu, F./Szabó, M., New data on the Roman temporary camps in Șureanu Mountains, Acta Musei Napocensis 57/1, 63-88.

\section{MATEESCU-SUCIU/GHEORGHIU/GĂZDAC 2016}

Mateescu-Suciu, L./Gheorghiu, G./Găzdac, C., Relaţii comerciale/Trade. In: Neamțu, C./Florea, G./Gheorghiu, G./Bodo C. (eds.), Incursiuni dacice în spațiul virtual (ClujNapoca: Mega Publishing House), 99-128.

\section{OLTEAN/FONTE 2021}

Oltean, I./Fonte, J., GIS Analysis and Spatial Networking Patterns in Upland Ancient Warfare: The Roman Conquest of Dacia, Geosciences 11, 1-17, https://doi.org/10.3390/ geosciences 11010017

\section{PETAC/POPA 2018}

Petac, E./Popa, N., Consideraţii asupra tezaurului monetar roman încheiat la Traian descoperit pe Dealul Prihodiştii (Grădiştea de Munte, com. Orăştioara de Sus, jud. Hunedoara) in anul 2002. In: Munteanu, L./Ciprian-Dorin, N. (eds.), Studia Numismatica et Archaeologica. In honorem magistri Virgilii Mihailescu-Bîrliba oblate [Bibliotheca Memoriae Antiquitatis 29], (București/Piatra Neamț: Academiei Române), 193-212.

\section{PAVEL 2017}

Pavel, C., Detectorism, Braconaj, Arheologie, Dilema Veche, 717, 16-22, noiembrie.

\section{STEFAN 2005}

Stefan, A. S., Les Guerres daciques de Domitien et de Trajan. Architecture militaire, topographie, images et histoire [Collection de l'École Française de Rome 353] (Rome: École Française de Rome). 


\section{CATALOGUE OF COINS FROM THE HOARD FOUND WITHIN THE PRISACA HILL GARRISON ${ }^{18}$}

\section{ROMAN REPUBLIC}

1. Furius Purpurio

Mint: $\quad$ Rome

Dating: $\quad 169-158$ BC

Diameter: 18.5 x 17.7 mm; Weight: 3.47 g; Axis: 7

Obv: $\quad \mathrm{X}$

Helmeted head of Roma, right.

$R v$ :

PVR

exergue: ROMA

Dioscuri galloping right; in linear frame, inscription. Line border.

Catalogue: RRC, 187/1

2. M. Atilius Saranus

Mint: $\quad$ Rome

Dating: 148 BC

Diameter: 20.1 x 19.1 mm; Weight: 3.88 g; Axis: 3

Obv: $\quad$ SARAN X

Helmeted head of Roma, right. Border of dots.

Rv: $\quad$ M.ATIL

exergue: ROMA

Dioscuri galloping right; in linear frame, inscription. Line border.

Catalogue: RRC, 214/1b

3. Q. Marcius Philippus

Mint: $\quad$ Rome

Dating: 129 BC

Diameter: 18.3 x $17.4 \mathrm{~mm}$; Weight: $3.77 \mathrm{~g}$; Axis: 2

Obv: $\quad \mathrm{X}$ (crossed)

Helmeted head of Roma, right; behind, denominational mark. Border of dots.

Rv: $\quad$ Q.PILIPV $[s]$

exergue: ROMA

Horseman galloping right, wearing crested helmet, holding reins in left hand and spear in right hand; behind,

helmet with goat's horns .

Catalogue: RRC, 259/1

4. C. Cassius

Mint: $\quad$ Rome

Dating: $126 \mathrm{BC}$

Diameter: 18.4 mm; Weight: 3.86 g; Axis: 6

Obv: $\quad \mathrm{X}$ (crossed)

Helmeted head of Roma, right. Behind, denominational mark. Border of dots.

$R v$ :

C.CASSI

exergue: ROMA

Libertas in quadriga, right, holding reins and rod (vindicta) in left hand and pileus in right hand . Line border. Catalogue: RRC, 266/1

5. L. Thorius Balbus

Mint: $\quad$ Rome

Dating: $\quad 105$ BC

Diameter: 20.6 x $18.4 \mathrm{~mm}$; Weight: $3.80 \mathrm{~g}$; Axis: 6

Obv: $\quad$ I S M R

Head of Juno Sospita right, wearing goat-skin. Border of dots.

Rv: $\quad$ L.THORIVS

exergue: BALBVS

Bull charging right; above, control-mark . Border of dots.

\footnotetext{
${ }_{18}$ Due to the low-quality photos provided to us, we are unable to publish them in this study. The technical details (diameter(s), weight, axis) are based on the
} expertise records attached to the files presented in court. 
Catalogue: RRC, 316/1

6. C. Marcius Censorinus

Mint: Rome

Dating: $88 \mathrm{BC}$

Diameter: 16.9 x 15.9 mm; Weight: 3.48 g; Axis: 12

Obv: inscription erased

Jugate heads of Numa Pompilius bearded and Ancus Marcius right.

Rv: $\quad$ inscription erased

Silhouette of Desultor riding right, wearing conical cap and holding whip in right hand.

Catalogue: RRC, 346/1a

7. P. Crepusius

Mint: $\quad$ Rome

Dating: $\quad 82 \mathrm{BC}$

Diameter: 17.7 x $16.1 \mathrm{~mm}$; Weight: $2.97 \mathrm{~g}$; Axis: 9

Obv: $\quad$ Laureate head (of Apollo?) right; behind, sceptre. Border of dots.

Rv: $\quad$ P CREPVSI

Horseman right, brandishing spear; behind, control mark. Border of dots.

Catalogue: RRC, 361/1

8. M. Junius Brutus

Mint: Rome

Dating: 54 BC

Diameter: 18.1 x 16.6 mm; Weight: 3.06 g; Axis: 6

Obv: $\quad$ inscription erased

Head of L. Junius Brutus, right.

Rv: $\quad$ AHALA

Head of C. Servilius Ahala, right. Border of dots. countermark $C$

Catalogue: RRC, 433/2

9. Mn. Acilius Glabrio

Mint: Rome

Dating: $\quad 49 \mathrm{BC}$

Diameter: $16.7 \mathrm{~mm}$; Weight: 3.15 g; Axis: 3

Obv: $\quad$ SALVTI[s]

Laureate head of Salus right. Border of dots.

Countermark: D

Rv: $\quad$ inscription erased

Silhouette of Valetudo standing left, resting left arm on column and holding snake in right hand.

Countermarks: F I

Catalogue: RRC, 442/1a

10. P. Clodius

Mint: Rome

Dating: $\quad 42 \mathrm{BC}$

Diameter: 18.5 x $17.5 \mathrm{~mm}$; Weight: $2.21 \mathrm{~g}$; Axis: 9

Obv: $\quad$ Laureate head of Apollo right; behind, lyre. Border of dots.

Rv: $\quad$ P.CLODIVS M.F

Diana standing facing, with bow and quiver over shoulder, holding lighted torch in each hand. Border of dots.

Catalogue: RRC, 494/23

11. P. Clodius

Mint: Rome

Dating: $\quad 42 \mathrm{BC}$

Diameter: 19.6 x $18.2 \mathrm{~mm}$; Weight: $2.95 \mathrm{~g}$; Axis: 5

Obv: $\quad$ Silhouette of the laureate head of Apollo right.

$R v: \quad$ [p].CLODIV[s $\mathrm{m} \mathrm{f}$ ]

Diana standing facing, with bow and quiver over shoulder, holding lighted torch in each hand. Border of dots. 
Catalogue: RRC, 494/23

12. M. Antonius

Mint: $\quad$ Travelling mint

Dating: $\quad 32-31 \mathrm{BC}$

Diameter: $17.7 \mathrm{~mm}$; Weight: $2.97 \mathrm{~g}$; Axis: 6

Obv: $\quad$ ANT.AVG III.VIR.R.P.C

Ship right, with sceptre tied with fillet on prow . Border of dots.

$R v: \quad$ LEG - VIII

Aquila between two standards. Border of dots.

Catalogue: RRC, 544/21

13. M. Antonius

Mint: $\quad$ Travelling mint

Dating: $\quad 32-31 \mathrm{BC}$

Diameter: 17.1 x $16.4 \mathrm{~mm}$; Weight: $2.47 \mathrm{~g}$; Axis: 3

Obv: $\quad$ ANT.AVG III.VIR.R.P.C

Ship right, with sceptre tied with fillet on prow . Border of dots.

$R v$ : $\quad$ inscription erased

Aquila between two standards.

Catalogue: RRC, 544

\section{ROMAN EMPIRE}

14. VESPASIAN

Mint: $\quad$ Rome

Dating: $\quad$ AD 70

Diameter: 17.5 x $16.3 \mathrm{~mm}$; Weight: $3.34 \mathrm{~g}$; Axis: 7

Obv: $\quad$ IMP CAESAR VESPASIANVS AVG

Rv: $\quad$ COS ITER - [tr pot]

Mars, helmeted, naked except for cloak round waist, advancing right, holding spear in right hand and aquila over left shoulder in left.

Catalogue: RIC II.1, 23

15. VESPASIAN

Mint: $\quad$ Rome

Dating: AD 70

Diameter: 17.4 x 16.9 mm; Weight: 2.88 g; Axis: 6

Obv: IMP CAESAR VESPASIANVS AVG

Rv: $\quad$ COS IT[er] - TR POT

Pax, draped. seated left, holding branch in extended right hand and winged caduceus in left.

Catalogue: RIC II.1, 29

16. VESPASIAN

Mint: $\quad$ Rome

Dating: AD 71

Diameter: 17.7 x $16.3 \mathrm{~mm}$; Weight: $2.44 \mathrm{~g}$; Axis: 6

Obv: [imp c]AES VESP AVG P M COS IIII

Head of Vespasian, laureate, right.

Rv: $\quad$ AVGVR // TRI POT

Simpulum, sprinkler, jug and lituus.

Catalogue: RIC II.1, 43

17. VESPASIAN

Mint: $\quad$ Rome

Dating: AD 74

Diameter: 18.8 x 17.5 mm; Weight: 2.71 g; Axis: 7

Obv: $\quad$ imp ca]ESAR - VESPASIANV[s aug] $\cap$

Head of Vespasian, laureate, right. 
$R v: \quad \quad$ PONT MAX - TR P COS $[\mathrm{v}] \curvearrowleft$

Pax, naked to waist, seated left, holding branch extended in right hand, left hand in lap. Catalogue: RIC II.1, 702

\section{VESPASIAN \\ Mint: $\quad$ Rome \\ Dating: AD 74}

Diameter: $18.5 \mathrm{~mm}$; Weight: $17 \mathrm{~g}$; Axis: 7

Obv: $\quad$ IMP CAESAR - VESPAS[ianus aug] $\cap$

Head of Vespasian, laureate, right.

Rv: $\quad$ PONT MAX - TR P COS V $\curvearrowleft$

Winged caduceus, upright.

Catalogue: RIC II.1, 703

19. VESPASIAN

Mint: $\quad$ Rome

Dating: $\quad$ AD 75

Diameter: 20 x 19.8 mm; Weight: 2.99 g; Axis: 6

Obv: $\quad$ IMP CAESAR - VESPASIANVS AVG $\curvearrowleft$

Head of Vespasian, laureate, right.

$R v: \quad$ PONT MAX - TR P COS VI

Pax, naked to waist, seated left, holding branch extended in right hand, left hand in lap. Catalogue: RIC II.1, 772

20. VESPASIAN

Mint: $\quad$ Rome

Dating: $\quad$ AD 75

Diameter: 20.3 x $17.3 \mathrm{~mm}$; Weight: $2.90 \mathrm{~g}$; Axis: 6

Obv: IMP CAESAR - VESPASIANVS AVG $\curvearrowleft$

Head of Vespasian, laureate, right.

$R v: \quad \quad$ PONT MAX - TR P COS VI

Pax, naked to waist, seated left, holding branch extended in right hand, left hand in lap.

Catalogue: RIC II.1, 772

21. VESPASIAN

Mint: $\quad$ Rome

Dating: AD 75

Diameter: 18.7 x $17.4 \mathrm{~mm}$; Weight: $3.13 \mathrm{~g}$; Axis: 7

Obv: $\quad$ IMP CAESAR - VESPASIANV[s aug] $\cap$

Head of Vespasian, laureate, right.

$R v$ : $\quad$ PONT MAX - TR P COS V[i]

Pax, naked to waist, seated left, holding branch extended in right hand, left hand in lap.

Catalogue: RIC II.1, 772

22. VESPASIAN

Mint: $\quad$ Rome

Dating: $\quad$ AD 75

Diameter: 18 x $17.1 \mathrm{~mm}$; Weight: $3.12 \mathrm{~g}$; Axis: 7

Obv: $\quad$ IMP CAESAR - VESPASIANV[S AVG $\curvearrowleft$

Head of Vespasian, laureate, right.

Rv: $\quad$ PONT MAX - TR P COS V[i]

Pax, naked to waist, seated left, holding branch extended in right hand, left hand in lap.

Catalogue: RIC II.1, 772

23. VESPASIAN

Mint: $\quad$ Rome

Dating: AD 75

Diameter: 18.5 x 17.9 mm; Weight: 2.99 mm; Axis: 7

Obv: IMP CAESAR - VESP[asianus] AVG $\curvearrowleft$

Head of Vespasian, bare, left. 
Rv: $\quad$ [pont max] - TR P COS V[i]

Pax, naked to waist, seated left, holding branch extended in right hand, left hand in lap.

Catalogue: RIC II.1, 773

24. VESPASIAN

Mint: $\quad$ Rome

Dating: AD 76

Diameter: 18.6 x $17.4 \mathrm{~mm}$; Weight: $2.97 \mathrm{~g}$; Axis: 6

Obv: $\quad$ IMP CAESAR - VESPASIAN[us aug] $\cap$

Head of Vespasian, laureate, right.

Rv: $\quad$ IOVIS - CVSTOS

Jupiter, bearded, naked, standing facing, sacrificing out of patera in right hand over low garlanded altar and holding long vertical sceptre in left.

Catalogue: RIC II.1, 849

25. VESPASIAN: TITUS (Caesar)

Mint: $\quad$ Rome

Dating: AD 77-78

Diameter: 18.8 x $18.1 \mathrm{~mm}$; Weight: 2.06 g; Axis: 7

Obv: $\quad$ T CAESAR - VESPASIANVS $\curvearrowleft$

Head of Titus, laureate, right.

Rv: $\quad$ ANNONA - AVG ties in her hands.

Annona, draped, seated left on throne, feet on stool, holding on her lap a sack of corn-ears open, holding the

Catalogue: RIC II.1, 972

26. VESPASIAN: DOMITIAN (Caesar)

Mint: $\quad$ Rome

Dating: $\quad$ AD 75

Diameter: 20.6 x 19.3 mm; Weight: 2.06 g; Axis: 6

Obv: $\quad$ CAES AVG F - DOMIT COS III $\curvearrowleft$

Head of Domitian, laureate, right.

Rv: $\quad$ PRI[n]CEPS - IVVENTVT

Spes standing, left holding flower in right and raising skirt with left.

Catalogue: RIC II.1, 788

27. VESPASIAN: DOMITIAN (Caesar)

Mint: $\quad$ Rome

Dating: AD 77-78

Diameter: 17.9 mm; Weight: 3.11 g; Axis: 6

Obv: $\quad$ CAES AVG F - DOMITIANVS $\Omega$

Head of Domitian, laureate, right.

Rv: $\quad \operatorname{COS}[\mathrm{v}]$

Wolf and twins; boat in exergue.

Catalogue: RIC II.1, 961

28. DOMITIAN

Mint: $\quad$ Rome

Dating: AD 88-89

Diameter: $18 \mathrm{~mm}$; Weight: 3.45 g; Axis: 7

Obv: $\quad$ IMP CAES DOMITIANVS AVG - GERM P M TR P VIII

Head of Domitian, laureate, right.

Rv: $\quad$ IMP XIX COS XIIII CENS P P P

Minerva standing right on top of rostral column, holding spear and shield; owl right.

Catalogue: RIC II.1, 657

29. DOMITIAN

Mint: $\quad$ Rome

Dating: AD 88-89

Diameter: 18.4 x 17.8 mm; Weight: 3.27 g; Axis: 7 
Obv: $\quad$ IMP CAES DOMIT AVG GERM P M TR P VIII

Head of Domitian, laureate, right.

Rv: $\quad$ IMP XIX COS XIIII CENS P P P

Minerva standing right on top of rostral column, holding spear and shield; owl right.

Catalogue: RIC II.1, 668

30. DOMITIAN

Mint: $\quad$ Rome

Dating: AD 88-89

Diameter: 18.4 x 17.8 mm; Weight: 3.38 g; Axis: 7

Obv: $\quad$ IMP CAES DOMIT AVG - GERM P M TR P VIII

Head of Domitian, laureate, right.

Rv: $\quad$ IMP XIX COS XIIII CENS P P P

Minerva standing right on top of rostral column, holding spear and shield; owl right.

Catalogue: RIC II.1, 668

31. DOMITIAN

Mint: $\quad$ Rome

Dating: AD 88-89

Diameter: 19 x 16.9 mm; Weight: 3.21 g; Axis: 6

Obv: $\quad$ IMP CAES DOMIT AVG GERM P M TR P VIII

Head of Domitian, laureate, right.

Rv: $\quad$ IMP XIX COS X[iiii] CENS P P P

Minerva standing left, holding thunderbolt and spear; shield at side.

Catalogue: RIC II.1, 669

32. DOMITIAN

Mint: $\quad$ Rome

Dating: AD 88-89

Diameter: 18.9 x $17.4 \mathrm{~mm}$; Weight: $3.06 \mathrm{~g}$; Axis: 6

Obv: $\quad$ IMP CAES DOMIT AVG - GERM P M TR P VIII

Head of Domitian, laureate, right.

Rv: $\quad$ IMP XIX COS XIIII CENS P P P

Minerva standing left, holding spear; shield at side.

Catalogue: RIC II.1, 670

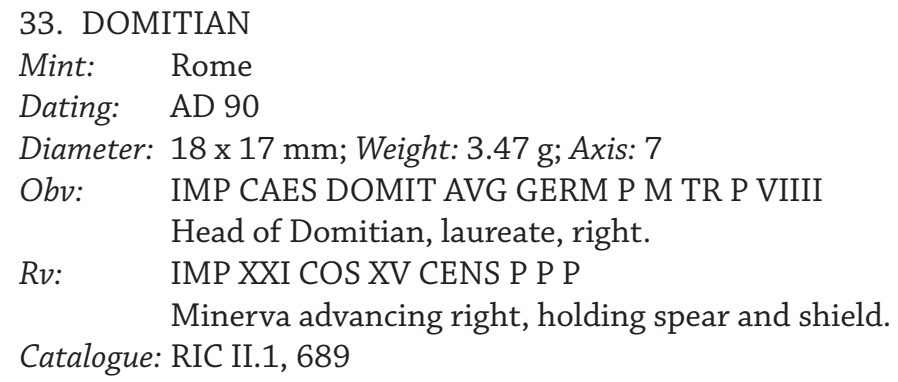

Diameter: 18.4 x 17.5 mm; Weight: 3.33 g; Axis: 7 
Obv: IMP CAES DOMIT AVG - GERM P M TR P X

Head of Domitian, laureate, right.

Rv: $\quad$ IMP XXI COS XV CENS P P P

Minerva standing right on top of rostral column, holding spear and shield; owl right.

Catalogue: RIC II.1, 720

36. DOMITIAN

Mint: $\quad$ Rome

Dating: AD 92-93

Diameter: 18.1 x 17.6 mm; Weight: 3.29 g; Axis: 7

Obv: $\quad$ IMP CAES DOMIT AVG GERM P M TR P XII

Head of Domitian, laureate, right.

Rv: $\quad$ IMP XXII COS XVI CENS P P P

Minerva advancing right, holding spear and shield.

Catalogue: RIC II.1, 739

37. DOMITIAN

Mint: $\quad$ Rome

Dating: AD 92-93

Diameter: 18.2 x 14.5 mm; Weight: 3.37 g; Axis: 7

Obv: $\quad$ IMP CAES DOMIT AVG GERM P M TR P XII

Head of Domitian, laureate, right.

Rv: $\quad$ IMP XXII COS XVI CENS P P P

Minerva standing right on top of rostral column, holding spear and shield; owl right.

Catalogue: RIC II.1, 740

38. DOMITIAN

Mint: $\quad$ Rome

Dating: AD 92-93

Diameter: 19.2 x 18.2 mm; Weight: 3.34 g; Axis: 7

Obv: $\quad$ IMP CAES DOMIT AVG GERM P M TR P XII

Head of Domitian, laureate, right.

$R v$ : $\quad$ IMP XXII COS XVI CENS P P P

Minerva standing left, holding thunderbolt and spear; shield at side.

Catalogue: RIC II.1, 741

39. DOMITIAN

Mint: $\quad$ Rome

Dating: AD 92-93

Diameter: $18.5 \mathrm{~mm}$; Weight: $3.24 \mathrm{~g}$; Axis: 6

Obv: $\quad$ IMP CAES DOMIT AVG GERM P M TR P XII

Head of Domitian, laureate, right.

Rv: $\quad$ IMP XXII COS XVI CENS P P P

Minerva standing left, holding thunderbolt and spear; shield at side.

Catalogue: RIC II.1, 741

40. DOMITIAN

Mint: $\quad$ Rome

Dating: AD 92-93

Diameter: 17.6 mm; Weight: 3.37 g; Axis: 7

Obv: $\quad$ IMP CAES DOMIT AVG - GERM P M TR P XII

Head of Domitian, laureate, right.

Rv: $\quad$ IMP XXII COS XVI CENS P P P

Minerva standing left, holding spear.

Catalogue: RIC II.1, 742

41. DOMITIAN

Mint: $\quad$ Rome

Dating: AD 94

Diameter: 19.6 x 19 mm; Weight: 3.34 g; Axis: 7 
Obv: $\quad$ IMP CAES DOMIT AVG GERM P M TR P XIIII

Head of Domitian, laureate, right.

Rv: $\quad$ IMP XXII COS XVI CENS P P P

Minerva advancing right, holding spear and shield.

Catalogue: RIC II.1, 766

42. TRAJAN

Mint: $\quad$ Rome

Dating: AD 101-102

Diameter: 18.7 x 17.6 mm; Weight: 3.55 g; Axis: 6

Obv: IMP CAES NERVA TRAIAN AVG GERM

Head of Trajan, laureate, right.

Rv: $\quad$ P M TR P - COS IIII P P

Hercules, naked, standing front on low base, holding club downwards in right hand and lion-skin over left arm.

Catalogue: RIC II, 49; MIR 14, 100a

43. TRAJAN

Mint: $\quad$ Rome

Dating: $\quad$ AD 102

Diameter: 18.5 x 17.4 mm; Weight: 2.72 g; Axis: 7

Obv: $\quad$ IMP CAES NERVA TRAIAN AVG GERM

Head of Trajan, laureate, right.

Rv: $\quad$ P M TR P COS IIII P P

Victory, naked to waist, standing front, head left, holding up wreath in right hand and palm in left.

Catalogue: RIC II, 58; MIR 14, 128b

44. TRAJAN

Mint: $\quad$ Rome

Dating: AD 102

Diameter: 18.4 x 16.4 mm; Weight: 3.18 g; Axis: 7

Obv: IMP CAES NERVA TRAIAN AVG GERM

Rv: $\quad$ P M TR P COS IIII P P

Victory, naked to waist, standing front, head left, holding up wreath in right hand and palm in left.

Catalogue: RIC II, 58; MIR 14, 128b 